\title{
Study on Corrosion Behavior of Pearlitic Rail Steel
}

\author{
S. Samal ${ }^{a,{ }^{*}}$, A. Bhattaacharyya ${ }^{\mathrm{b}}$ and S.K. Mitra ${ }^{\mathrm{b}}$ \\ ${ }^{a}$ Information Materials Lab., School of Materials Science and Engineering, Inha University, \\ 253, Yonghyun-Dong, Nam-Gu, Incheon 402-751, Korea \\ ${ }^{b}$ Department of Metallurgical and Material Engineering, National Institute of Technology, \\ Durgapur 713 209, India
}

*Corresponding Author: samasneha@gmail.com

\begin{abstract}
The present study is an attempt to find out the effect of environmental corrosion on the commonly used pearlitic rail steel. The cases of corrosion of rail under Indian environment have been studied. It has been found that in marine environment both the yield strength and tensile strength decreases with increasing corrosion rate. In acidic environment yield strength increased with increasing corrosion rate, although the tensile strength decreases with increasing corrosion rate.
\end{abstract}

Keywords: atmospheric corrosion, marine environment, quasi-cleavage fracture, peralitic steel.

\section{INTRODUCTION}

Modern Railway systems are subjected to use with fast trains and large loads. The primary requirement is structural integrity, which determines the suitability of steel for rail track applications. It depends on interactions between engineering parameters, material properties and the environment. The track material must obviously be capable of being manufactured into rails with a high standard of straightness and flatness in order to avoid surface and internal defects, which may cause failure.

Corrosion of rails has been recognized as one of the serious cause of damage railway track. The corrosion of rail along with cyclic loading may lead to corrosion fatigue failure of the railway track. Cases of failure of rails have come to light at load much below the safe load mainly due to deterioration of rail as a result of corrosion. It is therefore, essential that all Railway Engineers should have a broad knowledge of composition of rail and environmental 
effect on it. Railway track comes closely to different environment during its service life like seacoast environment, various humidity of the atmosphere, different temperature of the atmosphere and tunnel area which is acidic in nature. Strength of the rail material changes with the change in atmosphere.

Chowdhary have made investigation to assess the condition of rail, presence of corrosion activity and the extent of severity of corrosion [1]. They pointed out that presence of $\mathrm{NaCl}$ and $\mathrm{H}_{2} \mathrm{SO}_{4}$ in the atmosphere may cause concern. Bhadeshia [2] has studied the utility of different steel as rails namely pearlitic, bainitic etc. Pearlite presumably achieves a high resistance to wear because of the hard cementite and it's containment by the more ductile ferrite.

Studies on the fatigue and fracture of both pearlitic and bainitic rail steel have been reported by same researchers. Kenderian et-al [3] examined the dislocation movement during fatigue of pearlitic rail steel. Aglan and co-workers [4-5] analysed the mechanical and fracture behavior of bainitic rail steel, which has proved to be superior to pearlitic rail steel, so far mechanical properties are concerned. As it is established that corrosion may be considered as one of the precursor for the initiation of fatigue failure of rails, in the present work, an attempt has been made to study the corrosion behavior particularly in saline as well as acidic $\left(\mathrm{H}_{2} \mathrm{SO}_{4}\right.$ in tunnel) atmosphere along with its effect on mechanical properties of pearlitic rail steel.

\section{EXPERIMENTAL}

\subsection{Corrosion Test: Determination of Rate of Corrosion}

Rate of Corrosion (miles per year), m. p. y., is represented in equation 1

$$
\text { M.P.Y }=(534 \times \mathrm{w}) /(\mathrm{d} \times \mathrm{a} \times \mathrm{t})^{5}
$$

Where, $\mathrm{W}$ is the weight loss in $\mathrm{mg}, \mathrm{d}$ is the density in $\mathrm{gm} / \mathrm{cm}^{3}$, the surface area (a) of the specimen is in sq. inch and $\mathrm{t}$ is defined as the exposure time in hrs.

\subsection{Experimental Procedure}

Volume of the specimen is determined by displacement of water method. We were taken measuring beaker in which the sample could be totally submerged without overflow of water. We observed the level indicating the volume of the water without sample and with sample. The difference of the two volumes indicates the volume of the sample. Then we were taken corrosion solution and put the sample (3.4\% NaCl-solution or $\mathrm{H}_{2} \mathrm{SO}_{4}$ of $\mathrm{pH}-1.45,2.5$ and 3.46). When we maintained the temperature of the solution at $65^{\circ} \mathrm{C}$ then place the beaker on the electrical resistance heater for pre-determined length of time. Then the sample was withdrawn from the solution and taken the final weight. 
Corrosion rate of the sample can be determined as follows shown in equation 2

Corrosion rate $(\mathrm{gm} / \mathrm{cc})=\left(\mathrm{W}_{1}-\mathrm{W}_{2}\right) /\left(\mathrm{V}_{2}-\mathrm{V}_{1}\right)=\mathrm{W} / \mathrm{V}$

Where, density of Steel, $\mathrm{d}=8.17 \mathrm{gm} / \mathrm{cm}^{3}$ with exposure time for $7 \mathrm{hrs}$.

Density $\mathrm{D}=\mathrm{W}_{1} / \mathrm{V}=64.688 / 8=8.086 \mathrm{gm} /$ c.c.

Corrosion rate (m.p.y): $(534 \mathrm{~W}) /(\mathrm{D} \mathrm{A} \mathrm{T})=(534$ x 17) $/(8.086 \times 4.9445 \times 7)=32.4367$

\section{RESULTS \& DISCUSSION}

\subsection{Chemical Analysis}

Composition analysis report of as-received materials (Rail Steel) are represented below, in Table 1, which is obtained from Research and Control Laboratory (RC Lab.) of Steel Plant, Durgapur.

Pearlitic rail steel used in the present study, the chemical compositions are represented below in Table 2.

Table 1. Chemical analysis of rail steel samples

\begin{tabular}{|l|l|l|c|l|l|l|l|l|}
\hline Sample & $\mathrm{C}$ & $\mathrm{Mn}$ & $\mathrm{S}$ & $\mathrm{P}$ & $\mathrm{Si}$ & $\mathrm{Al}$ & $\mathrm{Cr}$ & $\mathrm{Mo}$ \\
\hline I. & 0.659 & 1.04 & 0.025 & 0.029 & 0.24 & 0.004 & 0.009 & 0.004 \\
\hline II. & 0.66 & 1.05 & 0.025 & 0.031 & 0.24 & 0.006 & 0.009 & 0.004 \\
\hline
\end{tabular}

Table 2. Samples with specification grade, chemical composition and mechanical properties.

\begin{tabular}{|c|c|c|c|c|c|c|c|c|}
\hline \multirow[t]{2}{*}{ Specification } & \multirow[t]{2}{*}{ Grade } & \multicolumn{5}{|c|}{ Chemical Composition, \% } & \multicolumn{2}{|c|}{$\begin{array}{l}\text { Mechanical } \\
\text { Properties }\end{array}$} \\
\hline & & $\mathrm{C}$ & $\mathrm{Mn}$ & $\begin{array}{l}\mathrm{P} \\
\max .\end{array}$ & $\begin{array}{l}S \\
\max .\end{array}$ & $\begin{array}{l}\mathrm{Si} \\
\max .\end{array}$ & $\begin{array}{l}\text { T.S. } \\
\text { MPa. }\end{array}$ & $\% \mathrm{E}$ \\
\hline IRS-T12/96 & 880 & $\begin{array}{l}0.60- \\
0.80\end{array}$ & $\begin{array}{l}0.80- \\
1.30\end{array}$ & 0.035 & 0.035 & $\begin{array}{l}0.10- \\
0.50\end{array}$ & $\begin{array}{l}880 \\
\min .\end{array}$ & $\begin{array}{l}10.0 \\
\min .\end{array}$ \\
\hline IRS-T18/86* & & $\begin{array}{l}0.40- \\
0.65\end{array}$ & $\begin{array}{l}0.80- \\
1.45 \\
\end{array}$ & 0.060 & 0.060 & $\begin{array}{l}0.03- \\
0.30\end{array}$ & $\begin{array}{l}860 \\
\min .\end{array}$ & $\begin{array}{l}10.0 \\
\min .\end{array}$ \\
\hline $\begin{array}{l}\text { Industrial Use } \\
\text { (as per IRS) }\end{array}$ & Rail. & $\begin{array}{l}0.60- \\
0.85\end{array}$ & $\begin{array}{l}0.80- \\
1.40\end{array}$ & 0.055 & 0.055 & $\begin{array}{l}0.10- \\
0.50\end{array}$ & $\begin{array}{l}840 \\
\min .\end{array}$ & $\begin{array}{l}10.0 \\
\min .\end{array}$ \\
\hline $\begin{array}{l}\text { Industrial Use } \\
\text { (result of pres }\end{array}$ & $\begin{array}{l}\text { Rail. } \\
\text { nt study) }\end{array}$ & $\begin{array}{l}0.659- \\
0.66\end{array}$ & $\begin{array}{l}1.04- \\
1.05\end{array}$ & $\begin{array}{l}0.029- \\
0.031\end{array}$ & 0.025 & 0.24 & 905 & 7.5 \\
\hline
\end{tabular}

* For IRS: T-12/96, Hydrogen content <3ppm and Al max 0.02\% 


\subsection{Corrosion Test}

Corrosion tests were carried out in two different mediums such as in $3.4 \% \mathrm{NaCl}$ solution at $\mathrm{RT}, 45^{\circ} \mathrm{C}$ and $65^{\circ} \mathrm{C}$ and sulfate medium $\left(\mathrm{H}_{2} \mathrm{SO}_{4}, \mathrm{pH}-1.49\right)$ at $\mathrm{RT}, 45^{\circ} \mathrm{C}$ and $65^{\circ} \mathrm{C}$. Experiments were carried out in the VOLTALAB 21, keeping duration of time for 3 hours. The results are represented in Table 3.

Table 3. Rate of corrosion of pearlitic rail steel in different environment

\begin{tabular}{|c|c|c|c|c|c|c|}
\hline Test No. & Test-1 & Test-2 & Test-3 & Test-4 & Test-5 & Test-6 \\
\hline Sample No & $\begin{array}{l}\text { Sample } \\
\text { I }\end{array}$ & $\begin{array}{l}\text { Sample } \\
\text { II }\end{array}$ & $\begin{array}{l}\text { Sample } \\
\text { III }\end{array}$ & $\begin{array}{l}\text { Sample } \\
\text { IV }\end{array}$ & $\begin{array}{l}\text { Sample } \\
\text { V }\end{array}$ & $\begin{array}{l}\text { Sample } \\
\text { VI }\end{array}$ \\
\hline $\begin{array}{l}\text { Corrosion medium } \\
\text { / Environment }\end{array}$ & $\begin{array}{l}3.4 \% \\
\mathrm{NaCl}\end{array}$ & $\begin{array}{l}3.4 \% \\
\mathrm{NaCl}\end{array}$ & $\begin{array}{l}3.4 \% \\
\mathrm{NaCl}\end{array}$ & $\begin{array}{l}\mathrm{H}_{2} \mathrm{SO}_{4} \\
\mathrm{pH}-1.49\end{array}$ & $\begin{array}{l}\mathrm{H}_{2} \mathrm{SO}_{4} \\
\mathrm{pH}-1.49\end{array}$ & $\begin{array}{l}\mathrm{H}_{2} \mathrm{SO}_{4} \\
\mathrm{pH}-1.49\end{array}$ \\
\hline Test temperature & RT & $45^{\circ} \mathrm{C}$ & $65^{\circ} \mathrm{C}$ & RT & $45^{\circ} \mathrm{C}$ & $65^{\circ} \mathrm{C}$ \\
\hline $\begin{array}{l}\text { Initial wt. in gm } \\
\left(\mathrm{W}_{1}\right)\end{array}$ & 65.049 & 783.120 & 65.350 & 67.202 & 64.688 & 69.235 \\
\hline $\begin{array}{l}\text { Final wt. in gm } \\
\left(\mathrm{W}_{2}\right)\end{array}$ & 65.045 & 73.111 & 65.322 & 67.180 & 64.671 & 69.229 \\
\hline $\begin{array}{l}\text { Wt. loss in gm } \\
\text { (W) }\end{array}$ & 0.004 & 0.009 & 0.028 & 0.022 & 0.017 & 0.006 \\
\hline $\begin{array}{l}\text { Initial vol. in cc } \\
\left(\mathrm{V}_{1}\right)\end{array}$ & 90 & 90 & 85 & 90 & 90 & 90 \\
\hline $\begin{array}{l}\text { Final vol. in cc } \\
\left(\mathrm{V}_{2}\right)\end{array}$ & 88 & 99 & 93 & 98 & 98 & 98 \\
\hline $\begin{array}{l}\text { Total vol. in cc } \\
\left(\mathrm{V}=\mathrm{V}_{2}-\mathrm{V}_{1}\right)\end{array}$ & 8 & 9 & 8 & 8 & 8 & 8 \\
\hline $\begin{array}{l}\text { Exposure time in } \\
\text { hrs., (T) }\end{array}$ & 3 & 3 & 3 & 7 & 7 & 7 \\
\hline $\begin{array}{l}\text { Corrosion rate in } \\
\mathrm{gm} / \mathrm{cm} / \mathrm{s}, \\
\mathrm{r}=\mathrm{W} / \mathrm{VxT}\end{array}$ & $1.13 \times 10^{-8}$ & $8.12 \times 10^{-8}$ & $7.57 \times 10^{-8}$ & $2.57 \times 10^{-8}$ & $2.11 \times 10^{-8}$ & $0.69 \times 10^{-8}$ \\
\hline $\begin{array}{l}\text { Density in } \mathrm{gm} / \mathrm{cc} \text {. } \\
\text { (D) }\end{array}$ & 8.13 & 8.12 & 8.17 & 8.40 & 8.086 & 8.654 \\
\hline $\begin{array}{l}\text { Total exposed } \\
\text { surface area (A) in } \\
\text { sq. inch. }\end{array}$ & 5.056 & 5.5149 & 5.3 & 5.265 & 4.944 & 5.313 \\
\hline $\begin{array}{l}\text { Corrosion rate in } \\
\mathrm{mpy}=534 \mathrm{~W} / \mathrm{DAT}\end{array}$ & 17 & 36 & 115 & 38 & 32 & 10 \\
\hline
\end{tabular}




\subsection{Evaluation of Mechanical Properties}

Tensile tests were carried out on the as-received corroded pearlitic steel samples in a servo hydraulic closed loop Instron Machine (Model No. 8516) and the results obtained are shown below in Table 4.

Table 4. Effect of environment on mechanical strength of rail steel

\begin{tabular}{|c|c|c|c|c|c|c|c|}
\hline \multicolumn{4}{|c|}{$3.4 \% \mathrm{NaCl}$ solution in different temp } & \multicolumn{4}{|c|}{$\mathrm{H}_{2} \mathrm{SO}_{4}$ solution of different $\mathrm{pH}(1.49)$} \\
\hline \multirow[t]{2}{*}{$\begin{array}{l}\text { Temperature } \\
{ }^{\circ} \mathrm{C}\end{array}$} & $\begin{array}{l}\text { Corrosion } \\
\text { rate }\end{array}$ & $\begin{array}{l}\text { Strer } \\
\text { at ro }\end{array}$ & $\begin{array}{l}\mathrm{APa}) \\
\mathrm{np} .\end{array}$ & $\begin{array}{l}\text { Temperature } \\
{ }^{\circ} \mathrm{C}\end{array}$ & $\begin{array}{l}\text { Corrosion } \\
\text { rate }\end{array}$ & $\begin{array}{l}\text { Stre } \\
\text { at ro }\end{array}$ & $\begin{array}{l}\text { (MPa), } \\
\text { emp. }\end{array}$ \\
\hline & MPY & YS & UTS & & MPY & YS & UTS \\
\hline RT & 17 & 470 & 970 & RT & 38 & 416 & 865 \\
\hline 45 & 36 & 451 & 932 & 45 & 10 & 437 & 883 \\
\hline 65 & 115 & 401 & 824 & 65 & 2 & 461 & 950 \\
\hline
\end{tabular}

The microstructure of as-received is shown in Figure 1. The sample was taken from the transverse direction of the rail. Microscopic examination of samples in as received condition shows that structure contains nearly $82.5 \%$ pearlite and $17.5 \%$ ferrite. So, the microstructure indicates that the as received rail steel is medium to high carbon pearlitic rail steel. The micrographs of the pearlitic rail steel show a fine lamellar aggregate of soft and ductile ferrite and hard cementite.

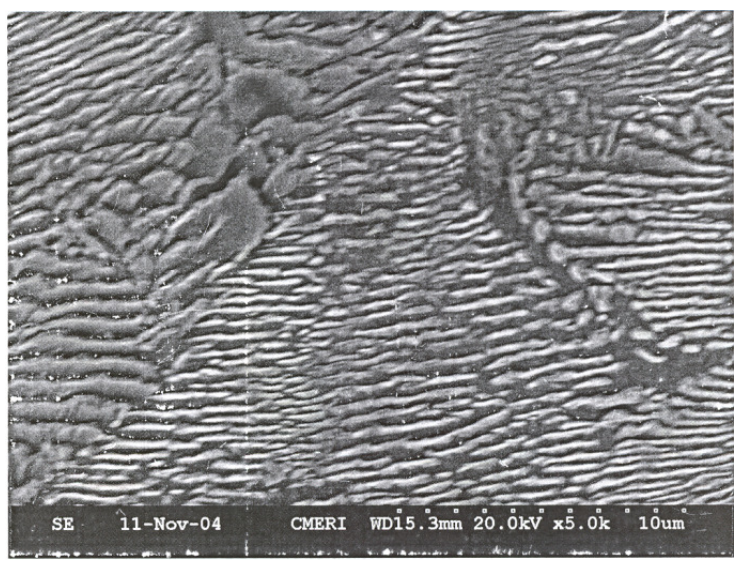

Figure 1: SEM micrograph of pearlitic rail steel (as-received).

The material (Industrial Use Rail) used in the present investigation was received from Durgapur Steel Plant (SAIL). The chemical composition of the steel determined by Research and Control Laboratory, Durgapur, indicates that the material is medium carbon steel containing over $1.0 \% \mathrm{Mn}$ and therefore the steel is expected to have reasonably high tensile/yield strength and high susceptibility due to the presence of higher amount of Mn. 
As-received Rail Steel samples were subjected to different environments like $3.4 \% \mathrm{NaCl}$ solution and $\mathrm{H}_{2} \mathrm{SO}_{4}$ solution of $\mathrm{pH}-1.49$ at $45^{\circ} \mathrm{C}$ and $65^{\circ} \mathrm{C}$, for the period of 3 hours. Corrosion pits of these different environment treated samples were examined using Scanning Electron Microscope (SEM). The scanning electron micrographs (Figure 2, 3, 4 and 5) show clearly the severity of corrosive environment on rails.

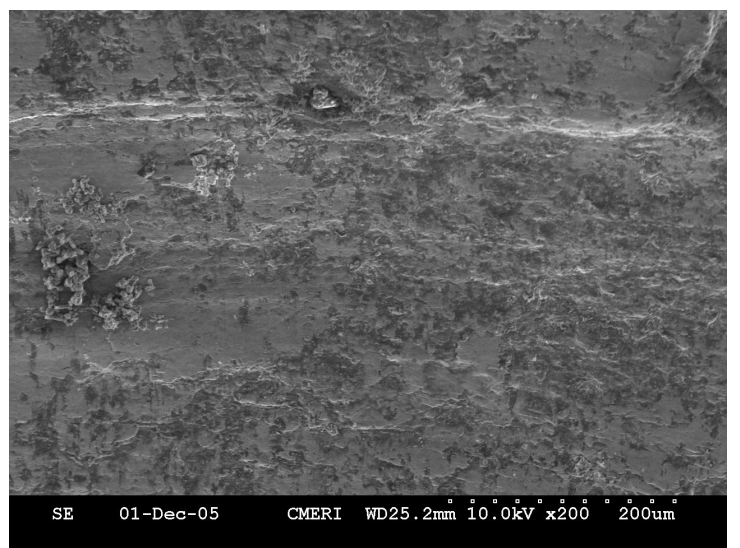

Figure 2: Scanning electron microscopy image on the surface of corrosion pit on rail in the medium of $3.4 \% \mathrm{NaCl}$ solution of $45^{\circ} \mathrm{C}$.

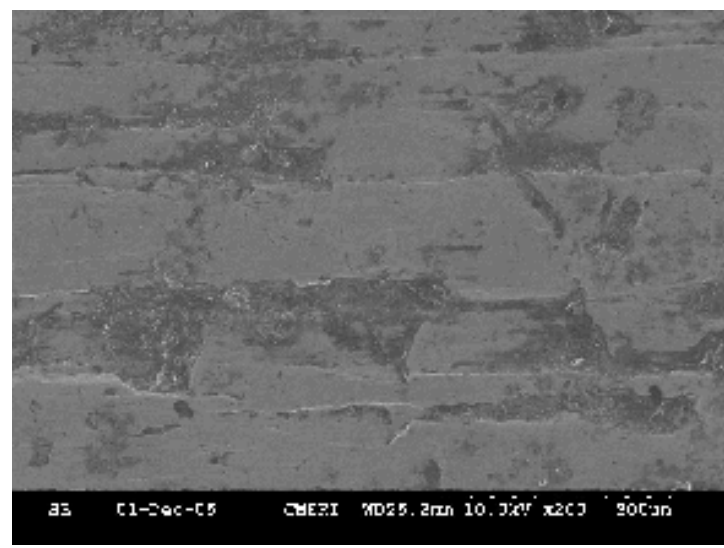

Figure 3: SEM electron microscopy image of corrosion pit on rail in the medium of $3.4 \% \mathrm{NaCl}$ solution of $65^{\circ} \mathrm{C}$.

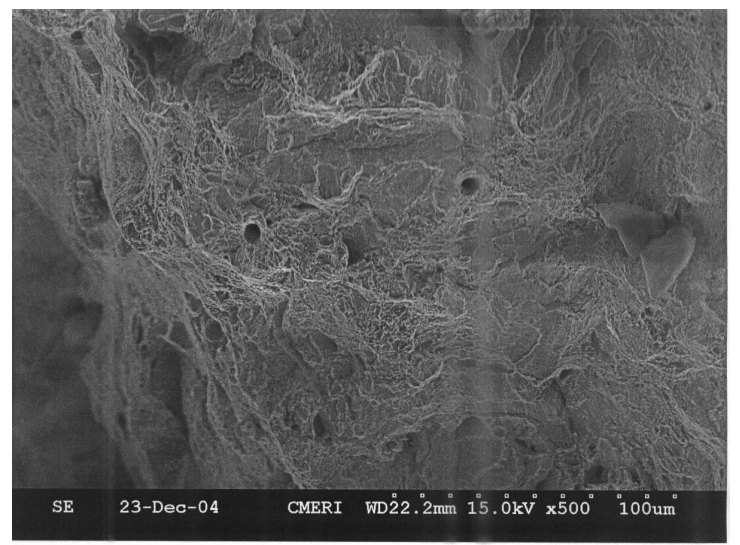


Figure 4: SEM micrograph of corrosion pit on rail in the medium of $\mathrm{H}_{2} \mathrm{SO}_{4}$ solutions $\mathrm{pH}-1.49$ at $45^{\circ} \mathrm{C}$.

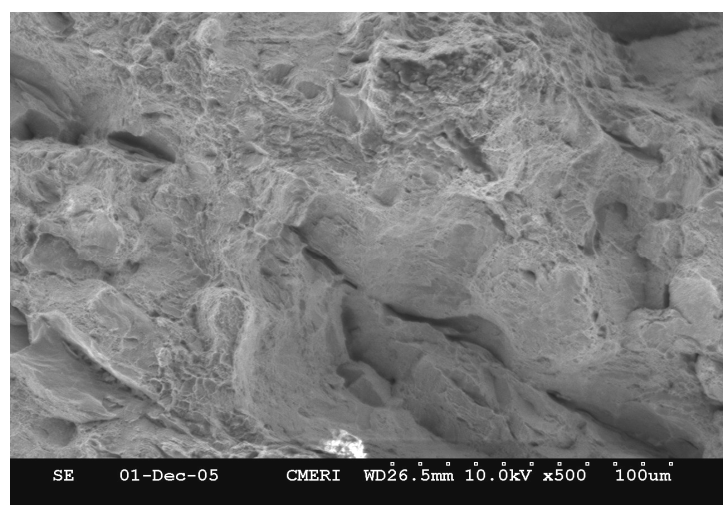

Figure 5: SEM micrograph showing the fracture surface.

( Fracture appeared after tensile test of rail steel sample treated in corrosion medium of $3.4 \% \mathrm{NaCl}$ solution of $65^{\circ} \mathrm{C}$ for the period of 3 hours)

The fractrography (Figure 6) of corroded sample shows mainly quasi-cleavage fracture with some marks of plastic deformation along with facet, which corresponds to the prior austenitic grain size. No distinct feature is observed.

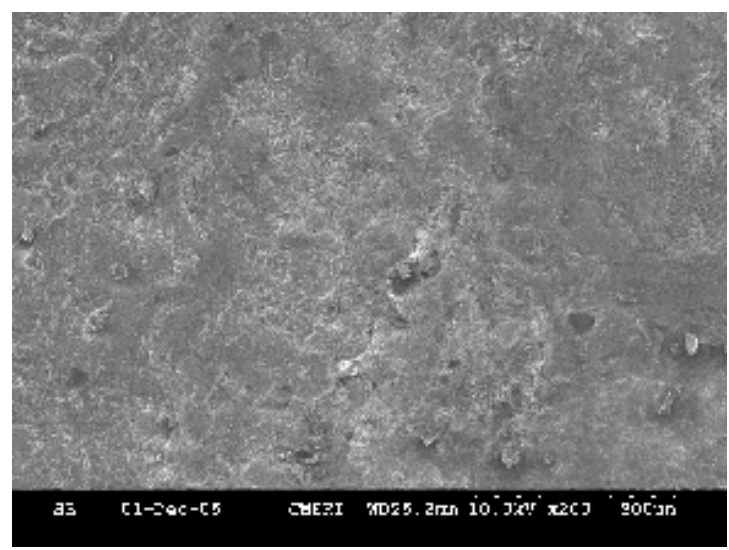

Figure 6: SEM micrograph at X500 magnification showing the fracture surface.

(Fracture appeared after tensile test of rail steel sample treated in corrosion medium of $\mathrm{H}_{2} \mathrm{SO}_{4}$ solution of $\mathrm{pH}-1.49$ for the period of 7 hours at $65^{\circ} \mathrm{C}$ )

By comparing the result of corrosion rate of pearlitic rail steel in different corrosive medium it can be predicted that corrosion rate of rail in $3.4 \% \mathrm{NaCl}$ solution, at room temperature is as high as 17 m.p.y. It seems that with increasing temperature, corrosion rate increases in the saline atmosphere. Contact medium of chloride accelerates the rail corrosion. Sodium chloride acts as strong electrolyte. It also interferes with the protection film already formed 
and thereby breaks the bond with metal thus promoting further corrosion. Tunnels in nonelectrified area due to presence of exhaust gases of steam engine, contains $\mathrm{H}_{2} \mathrm{SO}_{4}$. It was found that with $\mathrm{pH}$ value of 1.49 may cause serious corrosion.

It has seen that, the tensile test result and chemical composition of as received sample is comparable with the Indian Railway Standard.

The mechanical properties of rail steel are found to be affected by different corrosion medium. The relation between corrosion rate (m.p.y) of rail and tensile properties is shown in Table 4. Here the tensile specimen is subjected to tensile test after treating those samples in different corrosive medium and conditions for a pre-determined period of time. But tensile test of corroded samples were conducted at room temperature. The reason for the above results may be written as follows:

- In marine environment both the yield strength and tensile strength decreases with increasing corrosion rate i.e. with increasing temperature corrosion rate increases and strength decreases. This may be due to the protection film breaks the bond with metal with increasing corrosion rate at elevated temperature thus promoting further corrosion at every stress level.

- In acidic environment yield strength increased with increasing corrosion rate. At the high strength of acid (pH-1.49) there is a tendency of formation of strong passive layer over the surface of the specimen which causes increasing the yield strength. In acidic environment tensile strength decreases with increasing corrosion rate. This is because the passive layermetal bond does not stable at high stress level. So the passive layer may not have any influence on tensile strength.

\section{CONCLUSIONS}

The study of corrosion of pearlitic rail steel in different environment has yielded the following results such as:

1. In marine environment both the yield strength and tensile strength decreases with increasing corrosion rate.

2. In acidic environment yield is directly proportional to corrosion rate and tensile strength inversely proportional corrosion rate.

The above results of corrosion and mechanical studies on pearlitic rail steel in different environmental conditions reveal that, since mechanical properties of the above steel decreases significantly due to environmental corrosion, the periodic in-situ metallographic examination. Failure analysis of the rails reveals that it is necessary for careful investigation which will help to avoid premature failure of the rails. In highly aggressive corrosion zones like the sea coast areas and wide underground tunnels, the rail tracks made of pearlitic steel may be replaced with bainitic rail steel which is expected to have higher mechanical properties than pearlitic rail steels. 


\section{ACKNOWLEDGEMENTS}

The authors are thankful to Durgapur Steel plant, Durgapur for providing the research material along with its chemical composition. They are thankful to HOD, Metallurgical and Materials Engineering, NIT, Durgapur for giving permission to carry out the work

\section{REFERENCES}

1. S.K. Chowdhary, Journal of Metallurgy and material science, 43(4),2001, 265

2. H.K.D.H. Bhadeshia, "Steels for Rails", Encyclopedia of Material Science and Technology, 2002, p 1-7, Elsevier science.

3. S. Kenderian, T.P. Berndt, R.E. Green, B.B. Djardjevic, Material Science and Engineering, A 348, 2003, 90.

4. H.A. Aglan, Z.Y. Liu and M.F. Hassen, Journal of Mat. Proc. Tech., 2004, 0924-0136/s.

5. Mars G. Fontana, Corrosion Engineering, $3^{\text {rd }}$ edition, 1987, p 14, McGrow Hill Book Company, New York. 